\title{
POPULATION MIGRATIONS IN A POLYCENTRIC CONURBATION
}

\author{
DOI: http://dx.doi.org/10.18509/GBP.2018.45
}

UDC: 314.15(438)"1995/2016"

\section{Sławomir Pytel}

University of Silesia, Faculty of Earth Sciences, Poland

\begin{abstract}
The aim of the study is to show the volume, destinations and structure of current migrations in a polycentric conurbation as exemplified by the Katowice Conurbation (southern Poland). Throughout 1970s and 1980s, a period of rapid industrial development, until the economic transformation of 1990s, the region experienced large population influxes. Since 1993, however, population decline due to migration has been observable. This problem is particularly acute for large cities. Outflow from the cities accounts for the dominant migration destination. The results of this study show that the region faces a negative migration balance. The decreasing influx of working age migrants combined with the increasing outflow of pensioners result in rejuvenation of the cities and the emergence of a suburban zone around the core of the conurbation.
\end{abstract}

Keywords: population migrations, polycentric conurbation, post-industrial area

\section{INTRODUCTION}

Traditional industrial regions have been struggling with the problem of population decline already for many years. This results from two variables: the rate of natural increase and the migration balance. According to Runge [16], since 1990 these two factors fluctuated in the former Katowice Province. At first, in the years 1990-1991, the migration increase dominated over the natural one, however, the trend soon reversed and in 1992, the natural increase dominated over the one contributed by migrations. In 1993, the natural increase outnumbered the population outflow due to migrations, and in the years 1994-1995 emigration outnumbered the natural increase. In 1997, the natural increase rate was in fact negative, and the outflow due to migration deprived the region of even more inhabitants than this rate. Unfortunately, these changes result in a demographic decline. The aim of this study is to show the volume and destinations of current migrations by inhabitants of a polycentric conurbation in a traditional industrial region as exemplified by the Katowice Conurbation. The analysis accounts for immigration, emigration and the migration balance, the discussion also covers migration destinations and the migrants' sex and age structure.

In 2004, the province government adopted the Spatial Management Plan for the Silesian Province, acknowledging that the Katowice Conurbation consists of 14 large cities (each of them also functioning as a separate district - 'powiat'): Bytom, Chorzów, Dąbrowa Górnicza, Jaworzno, Gliwice, Katowice, Mysłowice, Piekary Śląskie, Ruda Śląska, Siemianowice Śląskie, Sosnowiec, Świętochłowice, Tychy, and Zabrze. The Katowice Conurbation is inhabited by about 2 million people (see Fig. 2). 


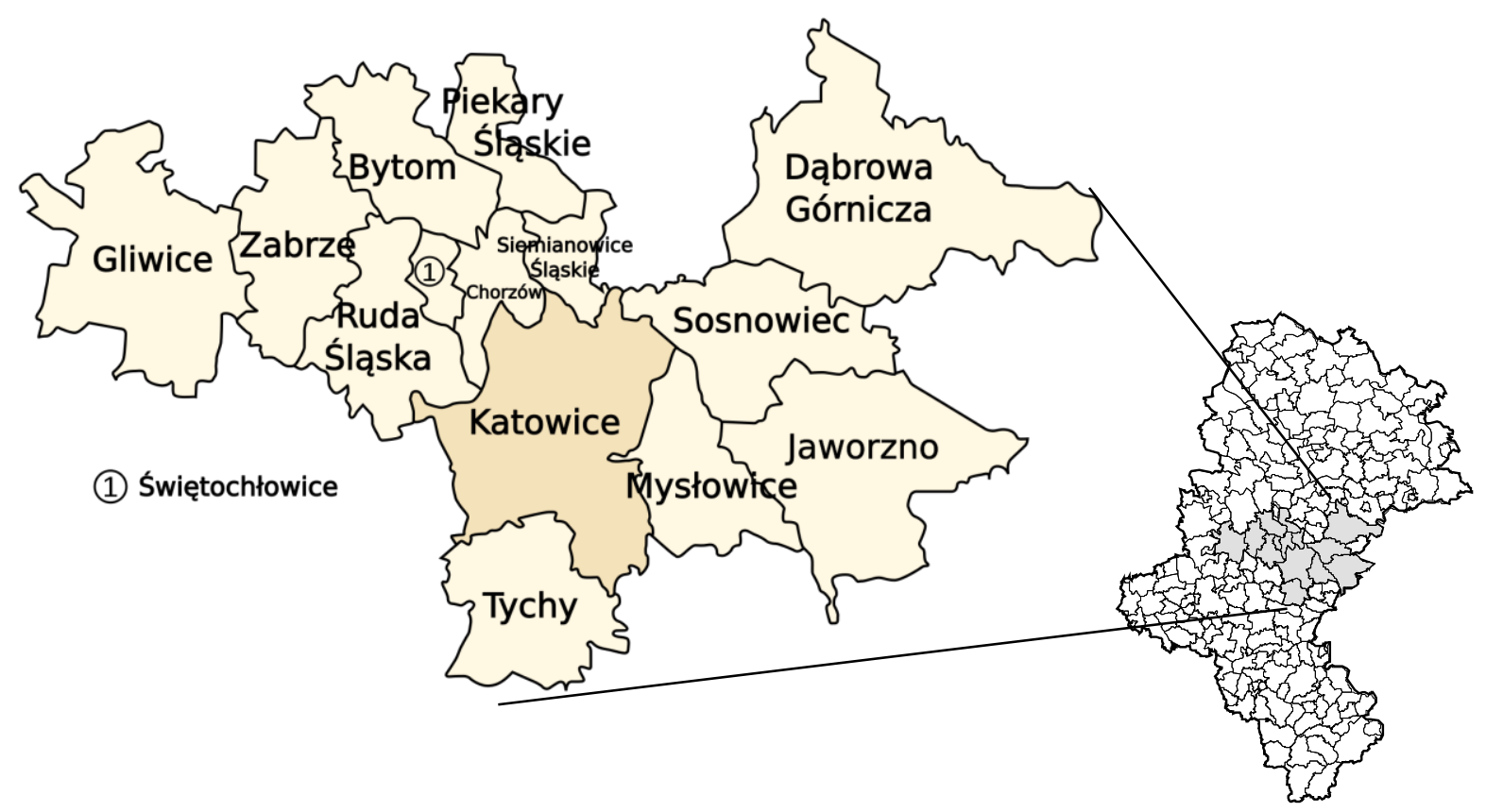

Figure1. Map of the Katowice Conurbation against the background of the Silesian Province Source: Prepared by the author on the basis of data from the Main Statistics Office (GUS)

Throughout 1970s and 1980s, a period of rapid industrial development, until the economic transformation of 1990s, the region experienced large population influxes. Immigration to the former Katowice Province decreased from 116,100 in 1979 to 39,000 in 1996, and the outflow decreased from 88,800 in 1982 to 44,100 in 1996 . Runge [16] argues that 1993 marks the beginning of a migration-induced population decline amounting to 2,500-6,400 people each year. This problem was limited almost entirely to cities, primarily the ones belonging to the Katowice Conurbation and the Rybnik Conurbation, which faced the largest numbers of migrations. Rural municipalities in the region were only a source of migration to the cities [17].

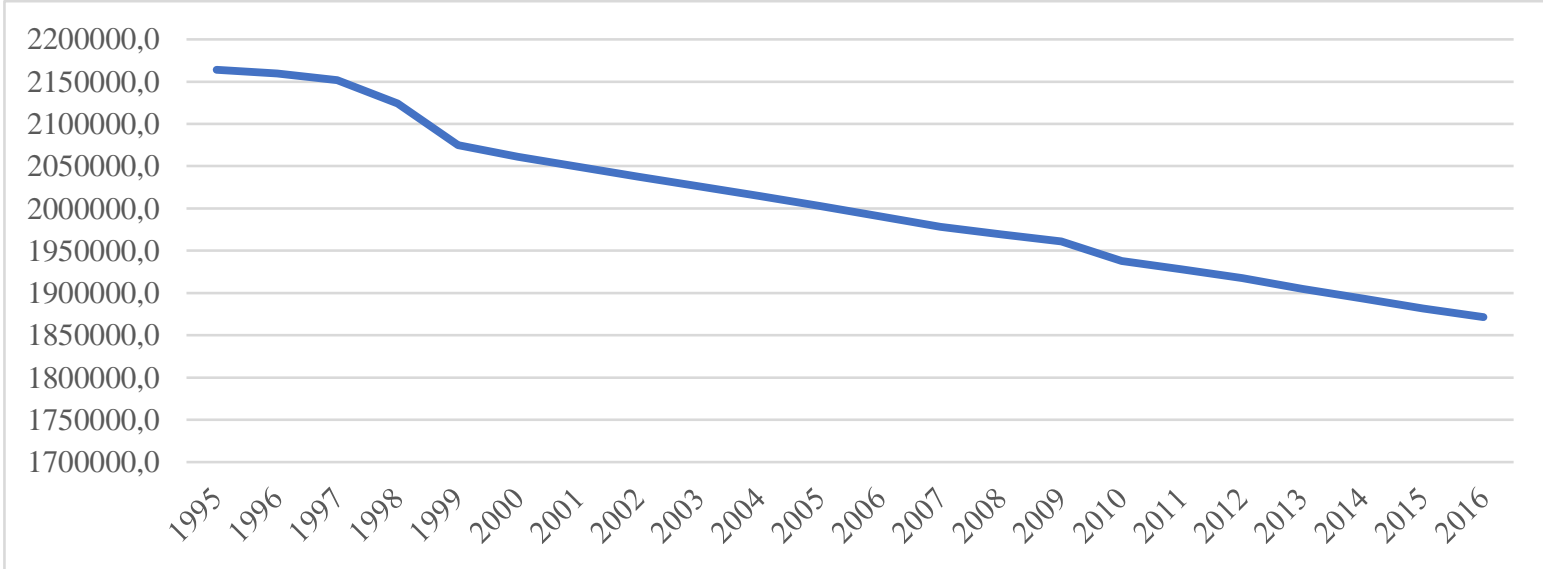

Figure 2. Population of the Katowice Conurbation in the years 1995-2016

Source: Prepared by the author on the basis of data from the Main Statistics Office (GUS)

Research on migrations within the Katowice Conurbation and the whole Silesian Province has been carried out, among others [1], [2], [4], [5], [6], [7], [9], [10], [11], [12], [13], [18], [19], [20], [21], [22], [23]. 
Since 1999, the Katowice Conurbation has had a negative internal migration balance (see Fig. 3). During the period under analysis, the annual population influx amounted to about 15,000 , and the outflow outnumbered the influx each year by about 5,000. The lowest volumes of both the influx and the outflow were recorded for 2001, when the influx reached about 13,600, and the highest - in 2007, when the outflow amounted to 23,500. Since 2013, the volumes of both the influx and the outflow have shown a consistent decrease. Considering external mobility, during the period under analysis emigration significantly outnumbered immigration. However, since 1998 a consistent decrease in emigration is observable, and in 2016 emigration reached the lowest volume so far 1,100 migrants. During the whole period under analysis, immigration stayed at the fairly steady level below 1,000 migrants yearly (see Fig. 4).

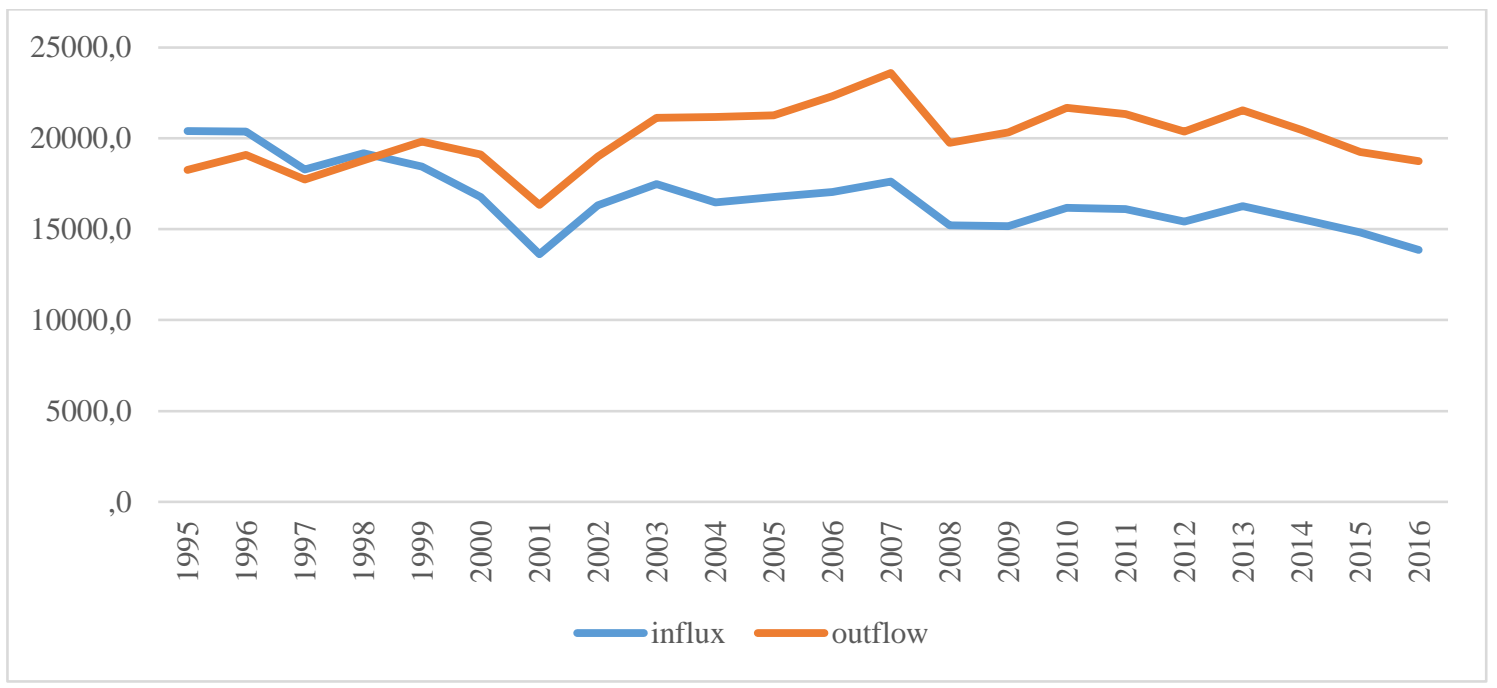

Figure 3. Officially registered population influx and outflow: internal mobility in the Katowice Conurbation in the years 1995-2016

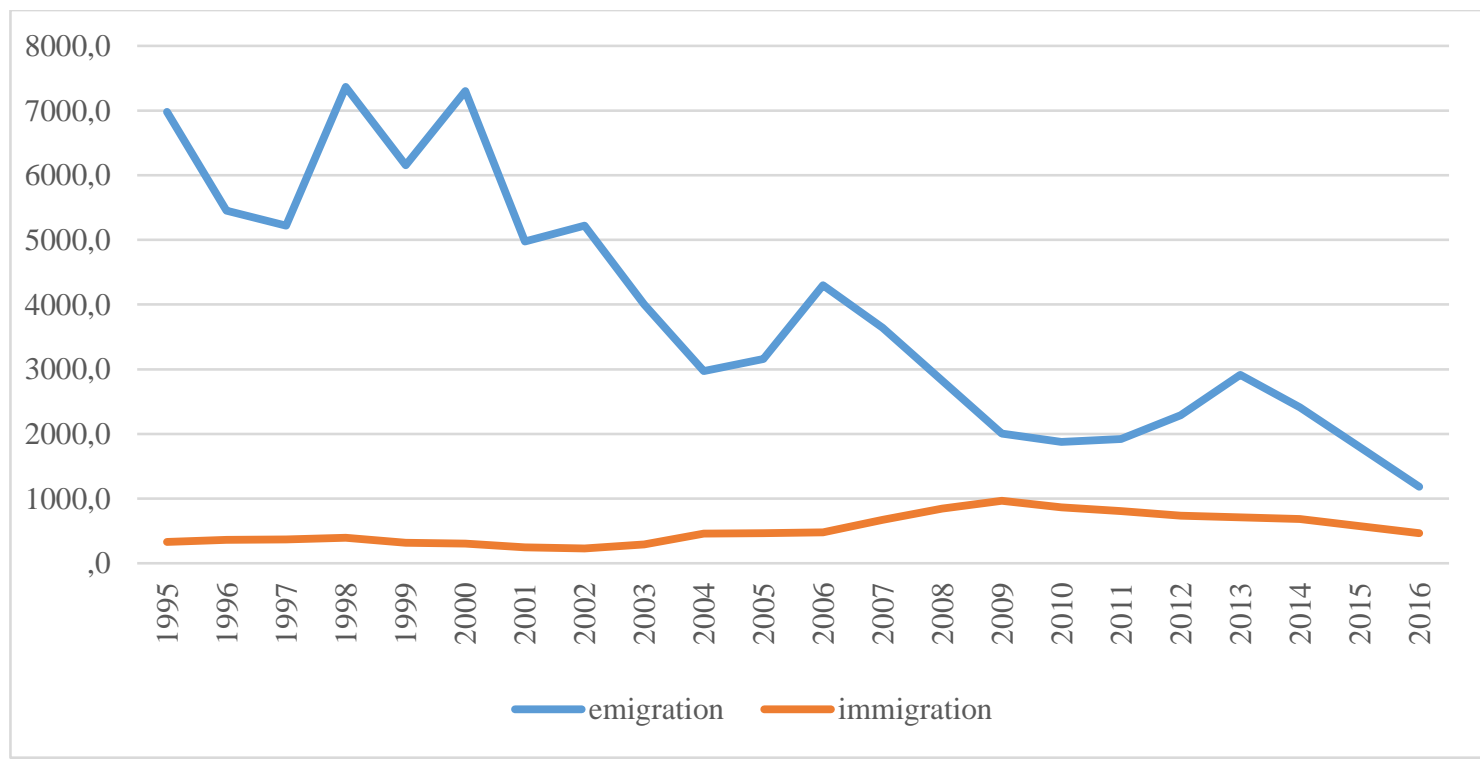

Figure 4. Officially registered population influx and outflow: external mobility in the Katowice Conurbation in the years 1995-2016 


\section{IMMIGRATION}

Immigration influxes vary across different cities of the Katowice Conurbation. The largest influx was experienced by Katowice, however, this results primarily from the sheer size of the city, which has nearly 300,000 inhabitants. In the years 1995-2005, Katowice gained over 31,000 inhabitants, and in the years 2006-2016 - over 28,000. Likewise, the period 2006-2016 meant lower influxes for the majority of the other cities of the conurbation. The worst situation was recorded in Dąbrowa Górnicza, Sosnowiec and Zabrze: each of these cities gained over 4,000 less inhabitants in the years 2006-2016 than in the previous period. Chorzów, Mysłowice and Piekary Śląskie are the only cities that have recently experienced a small increase in immigrations.

Table1. Total migration influx to the cities of the Katowice Conurbation in the years 1995-2016

\begin{tabular}{|l|r|r|r|}
\hline \multicolumn{1}{|c|}{ Total migration influx } & \multicolumn{1}{c|}{ 1995-2005 } & \multicolumn{1}{c|}{ 2006-2016 } & $1995-2016$ \\
\hline Bytom & 14887 & 13763 & 28650 \\
\hline Chorzów & 15459 & 15535 & 30994 \\
\hline Dąbrowa Górnicza & 16899 & 11964 & 28863 \\
\hline Gliwice & 17498 & 15095 & 32593 \\
\hline Jaworzno & 5454 & 4763 & 10217 \\
\hline Katowice & 31342 & 28744 & 60086 \\
\hline Mysłowice & 7346 & 7725 & 15071 \\
\hline Piekary Śląskie & 5024 & 5359 & 10383 \\
\hline Ruda Śląska & 10844 & 10586 & 21430 \\
\hline Siemianowice Śląskie & 7806 & 7183 & 14989 \\
\hline Sosnowiec & 20394 & 15848 & 36242 \\
\hline Świętochłowice & 6823 & 5783 & 12606 \\
\hline Tychy & 9826 & 9710 & 19536 \\
\hline Zabrze & 15724 & 11593 & 27317 \\
\hline
\end{tabular}

\section{EMIGRATION}

Also here, Katowice has the dominant position within the whole conurbation. In the years 1995-2016, over 75,000 people left Katowice, and the outflow for the period 2006-2016 outnumbers the one for the period 1995-2005 (see Table 2). High outflow volumes were also recorded for Sosnowiec $(51,000)$, Bytom $(39,000)$ and Gliwice $(39,000)$, where, similarly to Katowice, the population outflow increased in the more recent period.

When we consider the outflow from individual municipalities in 2015, the largest volumes were recorded for Katowice (3255), Sosnowiec (1963), Gliwice (1749), and Bytom (1684). Already since 1990s, the migration distance for individual municipalities decreases, especially for those that previously experienced large immigration. At present, the main migration destinations for any municipality are its neighbouring municipalities. This phenomenon can best be exemplified with the two biggest cities of the conurbation, i.e. Katowice and Sosnowiec. In 2015, the inhabitants of Katowice were most likely to move to Chorzów (383), Siemianowice Śląskie (260) or Mysłowice (244). Likewise, the inhabitants of Sosnowiec were also most likely to choose one of the neighbouring municipalities as their migration destination: Dąbrowa Górnicza (306), Będzin (197) or Katowice (170). 
Table 2. Total migration outflow from the cities of the Katowice Conurbation in the years 1995-2016

\begin{tabular}{|l|r|r|r|}
\hline Total migration outflow & $1995-2005$ & \multicolumn{1}{|c|}{$2006-2016$} & \multicolumn{1}{c|}{$1995-2016$} \\
\hline Bytom & 18721 & 20783 & 39504 \\
\hline Chorzów & 13597 & 14574 & 28171 \\
\hline Dąbrowa Górnicza & 14992 & 14944 & 29936 \\
\hline Gliwice & 18853 & 20951 & 39804 \\
\hline Jaworzno & 5977 & 6329 & 12306 \\
\hline Katowice & 36593 & 39059 & 75652 \\
\hline Mysłowice & 7288 & 8526 & 15814 \\
\hline Piekary Śląskie & 5261 & 6313 & 11574 \\
\hline Ruda Śląska & 11954 & 14345 & 26299 \\
\hline Siemianowice Śląskie & 7740 & 8763 & 16503 \\
\hline Sosnowiec & 25968 & 25897 & 51865 \\
\hline Świętochłowice & 6662 & 7672 & 14334 \\
\hline Tychy & 13898 & 14498 & 28396 \\
\hline Zabrze & 15248 & 17930 & 33178 \\
\hline
\end{tabular}

This may be explained by the fact that most migrants belonged to the working-age group, so probably they had a steady job and decided to move as a result of their improving financial status. Their migration destination, however, had to be located close enough to the place where they are employed. This is confirmed by one of Ravenstein's seven laws of migration, which argues that The great body of our migrants only proceed a short distance and migrants enumerated in a certain center of absorption - will ... grow less as distance from the center increases [8]. In other words, migration flows depend on the distance: the smaller the distance, the more migrants (the so-called Ravenstein's first law of migration). If distances are considerable, migrants usually settle in big industrial and commercial centres [14], [15].

Table 3. Main migration destinations for inhabitants of Katowice and Sosnowiec in 2015

\begin{tabular}{|l|r|l|r|}
\hline \multicolumn{2}{|c|}{$\begin{array}{c}\text { Main migration destinations for inhabitants of } \\
\text { Katowice (in persons) }\end{array}$} & \multicolumn{2}{c|}{$\begin{array}{c}\text { Main migration destinations for inhabitants of } \\
\text { Sosnowiec (in persons) }\end{array}$} \\
\hline Chorzów & 383 & Dąbrowa Górnicza & 306 \\
\hline Siemianowice Śląskie & 260 & Będzin & 197 \\
\hline Mysłowice & 244 & Katowice & 170 \\
\hline Mikołów & 145 & Czeladź & 100 \\
\hline Ruda Śląska & 136 & Mysłowice & 67 \\
\hline Tychy & 129 & Psary & 44 \\
\hline Sosnowiec & 97 & Kraków & 34 \\
\hline Bytom & 85 & Chorzów & 32 \\
\hline Gliwice & 72 & Jaworzno & 30 \\
\hline
\end{tabular}




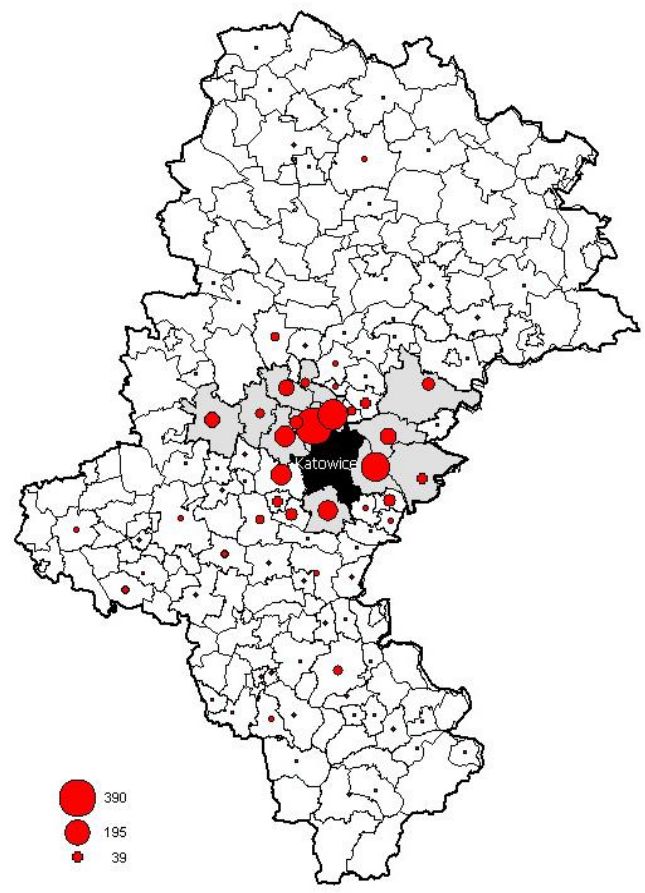

Outflow of people from Katowice

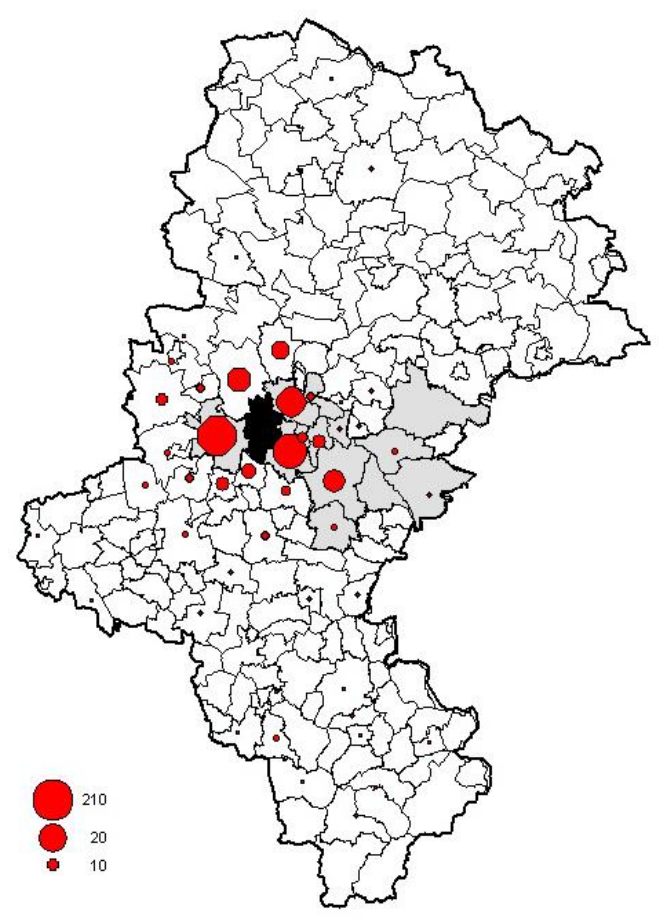

Outflow of people from Zabrze

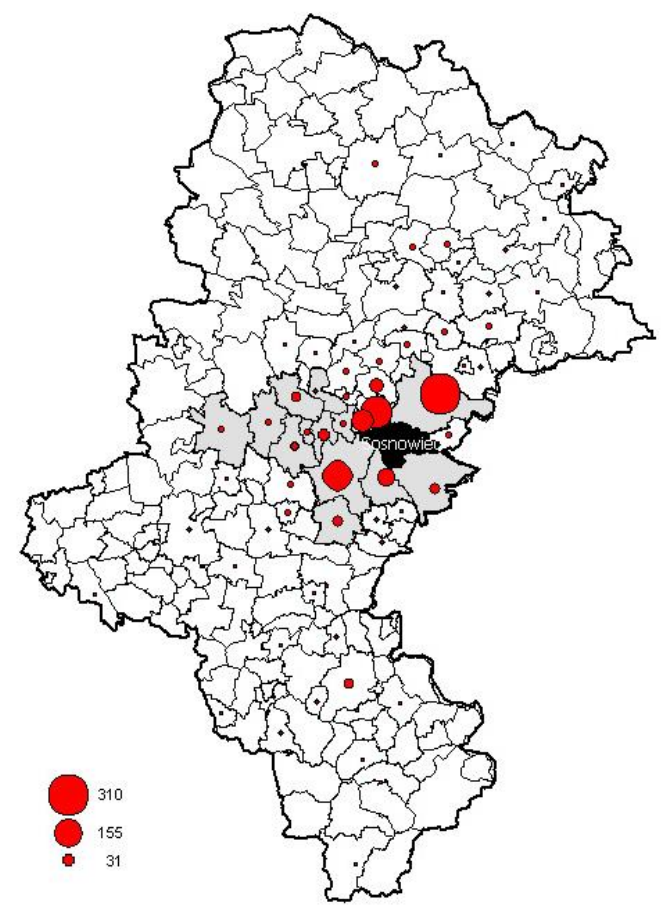

Outflow of people from Sosnowiec

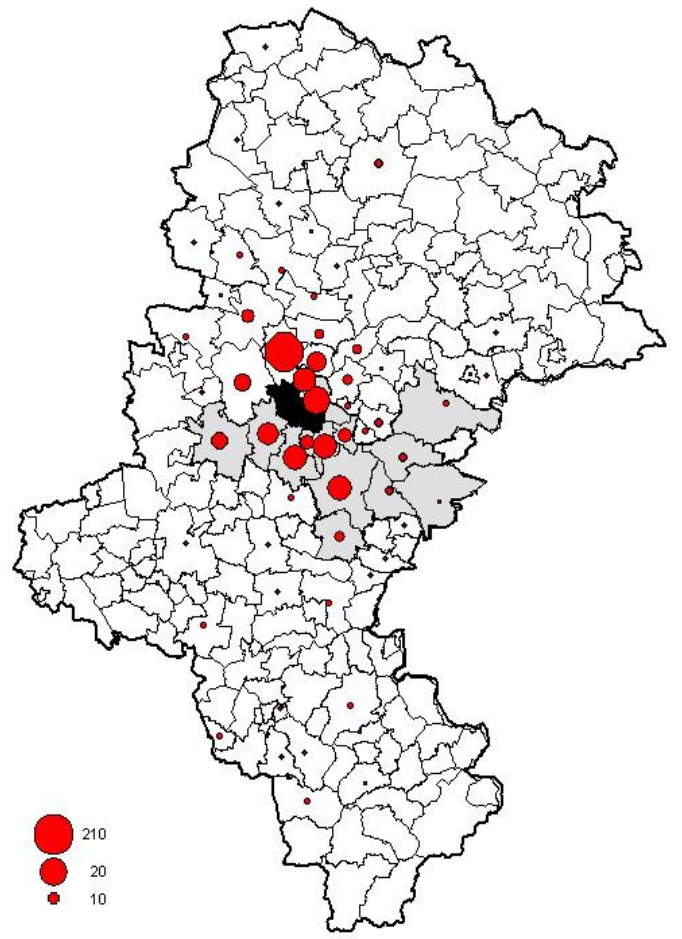

Outflow of people from Bytom 


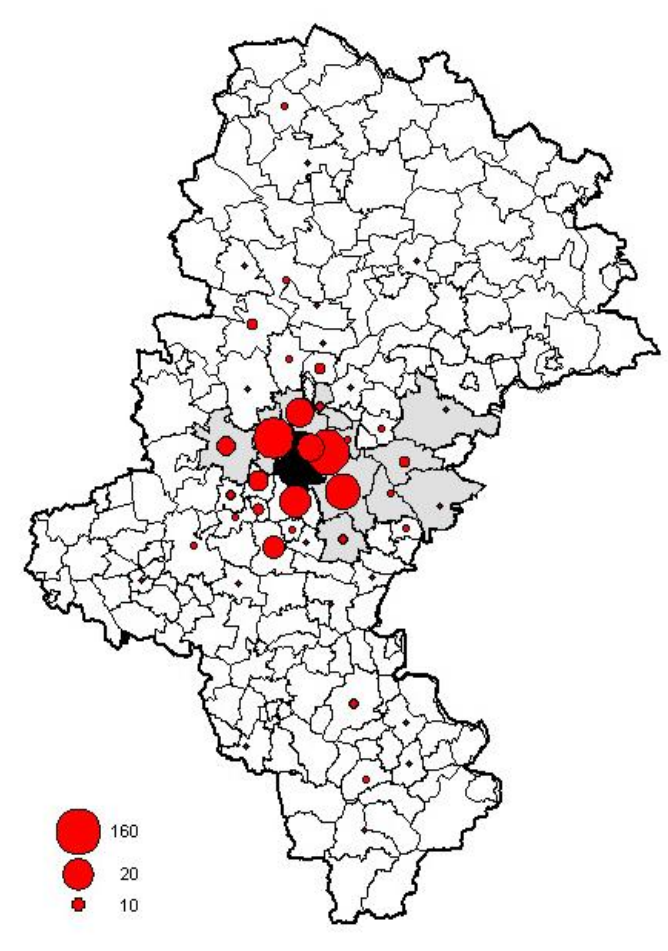

Outflow of people from Ruda Śląska

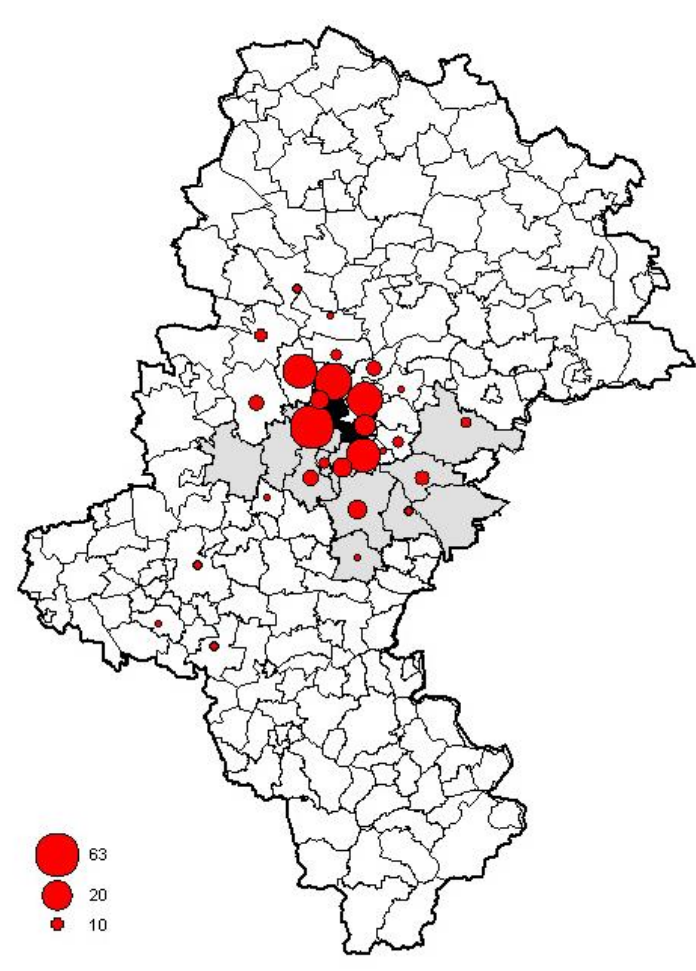

Outflow of people from Siemianowice Śląskie

Figure 5. Main migration destinations for inhabitants of selected cities of the Katowice Conurbation in 2015 (in persons)

\section{MIGRATION BALANCE}

In the years 2005-2016, the cities of the Katowice Conurbation had negative values of the migration balance for all the age groups under analysis. The migration balance for the pre-working age and working age populations remained at the level of about -500 persons annually, and for the post-working age population - at the level of about -200 annually (Fig. 6). For working age migrants, the most important reason for migration is the possibility of finding employment and good commuting opportunities. For post-working age migrants, in turn, clean air and a beautiful landscape play an important role, so it is popular among inhabitants of the Katowice Conurbation to own a second home in the southern part of the Silesian Province. While they are still employed, they build a house in this area, which they at first only visit at weekends. When they retire, this house becomes their migration destination [3] 


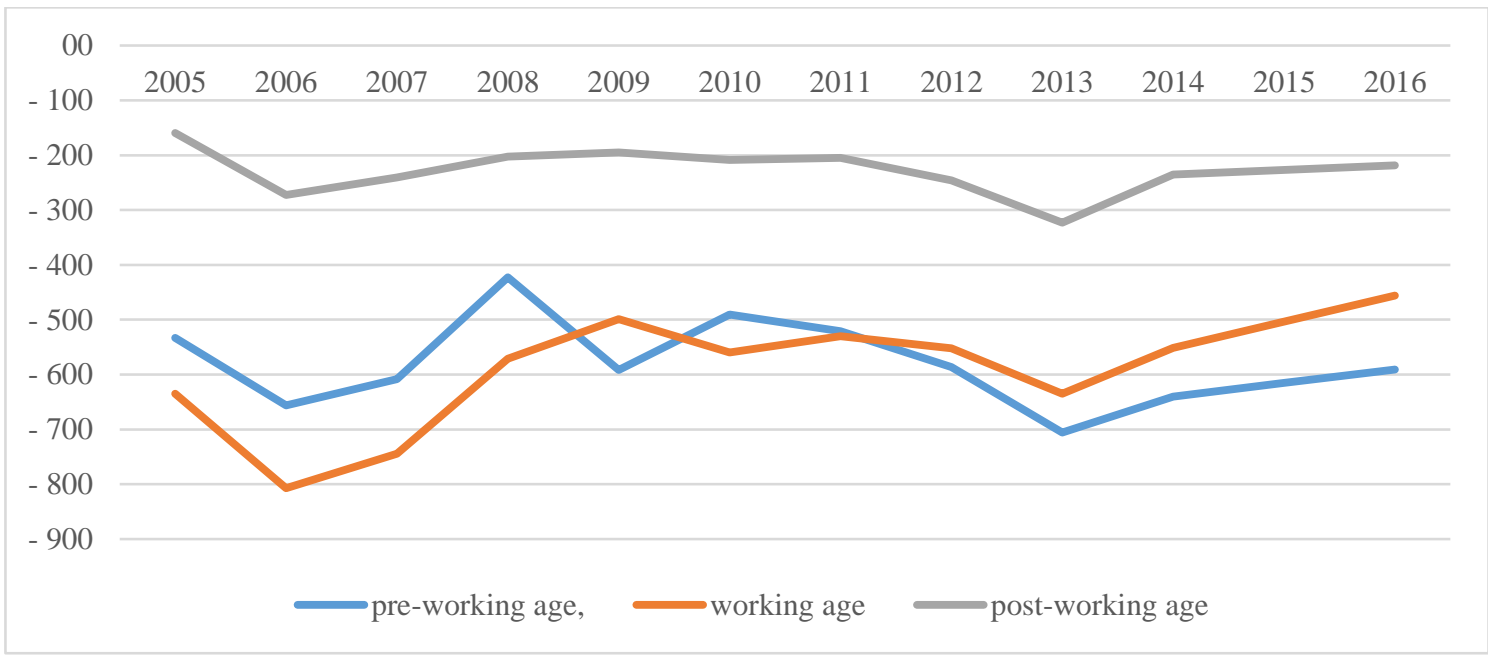

Figure 6. Migration balance in the Katowice Conurbation according to age group in the years 2005-2016

At present, positive values of the migration balance are recorded for municipalities located in the southern and the northern parts of the Silesian Province. We can clearly discern a ring of municipalities with a positive migration balance surrounding both Bielsko-Biała and Częstochowa. In addition, an emerging zone of municipalities with a positive migration balance is observable around the conurbation itself.

\section{MIGRATION STRUCTURE ACCORDING TO MIGRANTS' SEX AND AGE}

In 2016, the most mobile age groups were the ones between 25 and 29 as well as 30 and 34 years of age. In total, over 4,700 people from these age groups settled in the Katowice Conurbation, while over 5,000 left (Fig. 8). City dwellers were the most likely to migrate, and they predominantly chose other cities as their migration destinations. However, the domination of the population outflow from the cities over the influx means that the overall share of urban population decreases in the Silesian Province. At present, an increased outflow of post-working age migrants is observable (Fig. 8). This phenomenon was to be expected, considering the fact that the people who came to work in Silesia in 1970s and 1980 s are retiring now. This causes a rejuvenation of the population.

The overall structure of the population outflow in the years 2010-2016 shows the biggest share of migrants aged 18-40, however, there is a clear increase in the share of migrants aged 50 and more. Among the 50+ age group, there are almost twice as many emigrants as immigrants. This shape of sex and age pyramid is caused by retirement, especially of coal miners, who often migrate to the area from which they originated. 


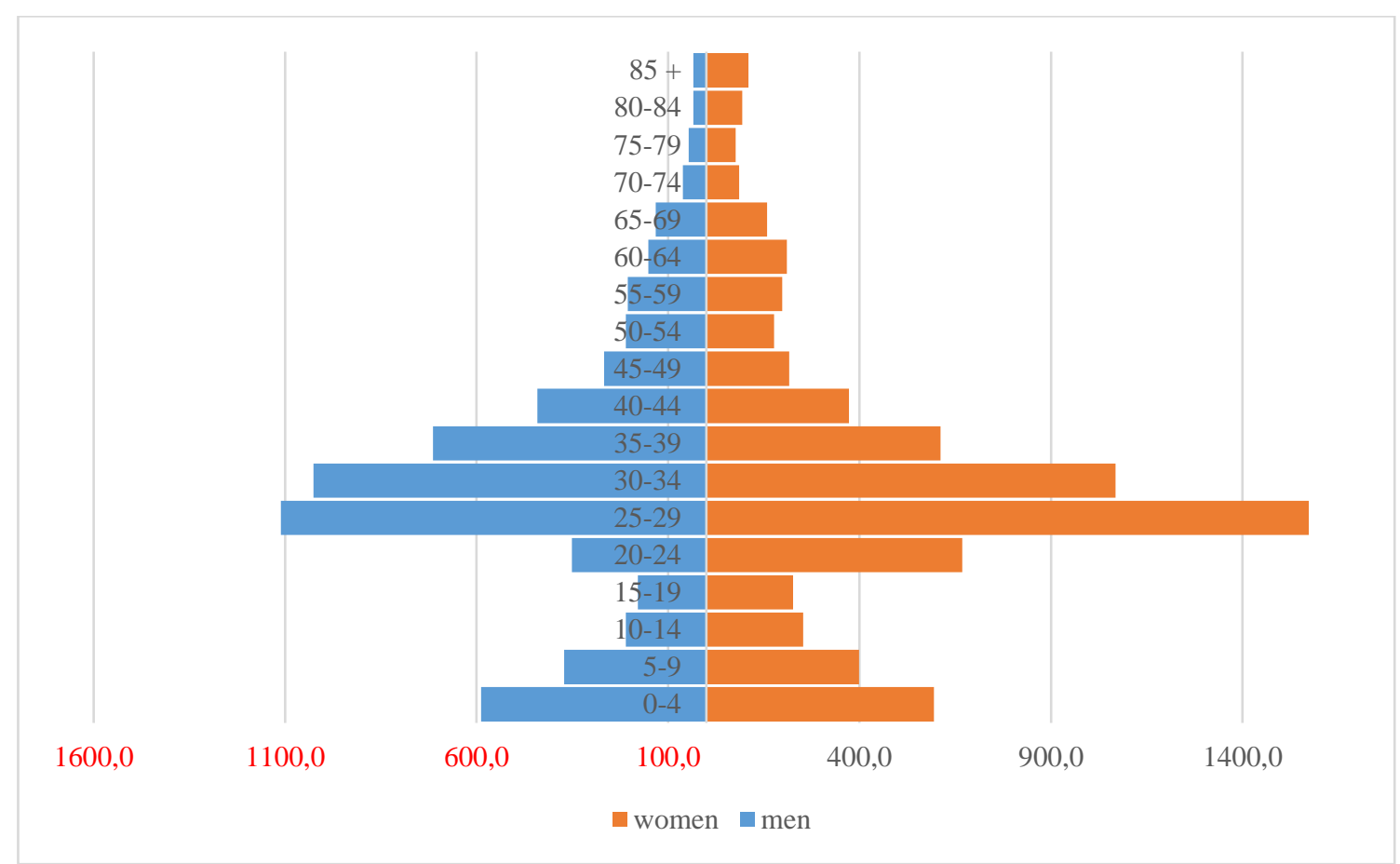

Figure7. Sex and age structure for the migration inflow to the Katowice Conurbation in 2016

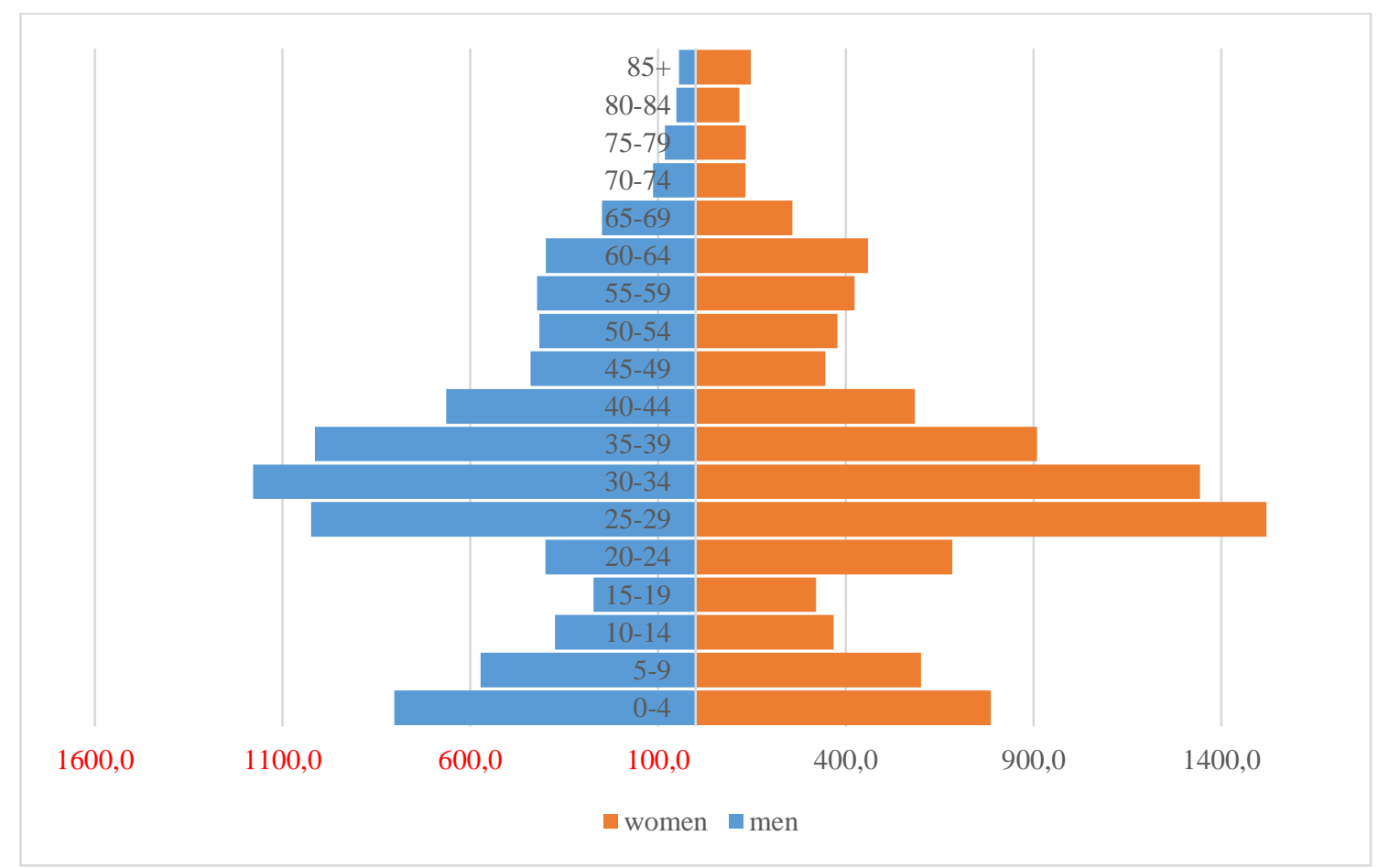

Figure 8. Sex and age structure for the migration outflow from the Katowice Conurbation in 2016

\section{SUMMARY}

During the industrial period, the population of the Katowice Conurbation was mostly shaped by the large migration inflow, however, this was followed by a period characterized by growing negative migration balance, which has remained negative until 
today. The factors that contributed to this trend are, on one hand, the general demographic cycle in Poland, and, on the other hand, the social and economic transformations in the region and the declining status of the cities that used to attract migrants.

Overall, the following conclusions may be drawn:

- since 1999, more people have been leaving the Katowice Conurbation than settling there,

- the influx of working age migrants has been decreasing,

- the dominating migration destination is from one city to another,

- the share of the urban population has been decreasing,

- the outflow of pensioner migrants has been increasing, which rejuvenates the cities,

- there is an emergent suburban zone around the core of the conurbation as well as in the southern and the northern parts of the Silesian Province,

- migrants who leave the cities of the conurbation predominantly choose one of the neighbouring municipalities as their migration destination.

\section{REFERENCES:}

[1] Chmielewska M., Sitek S., Zuzańska-Żyśko E. Around the Revitalisation of Post-Industrial Urban Spaces - Case Study of Metropolitan Association of Upper Silesia, [in:] Efe R., Cürebal I., Lévai L. (red.), GeoMed 2016. 4th International Geography Symposium. Book of Proceedings, Kemer, Antalya (Turkey), pp. 823-834, 2016

[2] Heffner K., \& Sołdra-Gwiżdż T. Migracje powrotne na Górny Ślask z socjologicznej perspektywy. Ośrodek Badań nad Migracjami, Inst. Studiów Społecznych UW. 1997

[3] Kłosowski F., \& Pytel S., \& Runge A., \& Sitek S., \& Zuzańska-Żyśko E. Rynek pracy w subregionie centralnym województwa ślaskiego, Prace Wydziału Nauk o Ziemi Uniwersytetu Śląskiego, Sosnowiec, 2013

[4] Kłosowski F., \& Runge J., Migracje ludności miast województwa ślaskiego w latach1977 1997, [in:] Szymańska D. (red.), Procesy i formy ruchliwości przestrzennej ludności w okresie przemian ustrojowych, Uniwersytet Mikołaja Kopernika, Toruń, pp. 121-133, 2000

[5] Kłosowski F., \& Runge J. Migration of the Population of Katowice Province in the Period 1977-1997, Polish Population Review, no. 17, pp. 110-118. 2000

[6] Kłosowski F., \& Runge J. Migracje ludności w gminach wiejskich województwa śląskiego (lata 1977-1999), Biuletyn Geograficzny, nr 1, Uniwersytet Mikołaja Kopernika, Toruń, pp.7786,2002

[7] Kłosowski F., \& Runge J. Migracje ludności w miastach województwa ślaskiego w latach 1977-2006, [in:] W. Świątkiewicz (red.), Górnośląskie Studia Socjologiczne. Seria nowa. T. 1, Instytut Socjologii UŚ, Katowice, pp.83-92, 2010

[8] Lee, E. S. A theory of migration. Demography 3 (1), 47-57, 1966

[9] Mielecka-Kubień Z. Migracje wojewódzkie na pobyt staty w województwie ślaskim w 2010 roku w świetle praw migracji EG Ravensteina. Studia Ekonomiczne 142, p. 24-40, 2013

[10] Pytel S., \& Sitek S., Składowe przyrostu rzeczywistego jako determinanty rozwoju ludności południowej części województwa ślaskiego, Biuletyn Geograficzny, Uniwersytet Mikołaja Kopernika, Toruń, pp. 167-173, 2002

[11] Pytel S., \& Sitek S., Czynniki kształtujace migracje w miastach przygranicznych powiatu cieszyńskiego, [in:] Przemiany demograficzne i jakość życia ludności, Słodczyk J., Rajchel D., red., Uniwersytet Opolski, Opole, pp. 171-179, 2004 
[12] Pytel S., \& Szkup R. Rola atrakcyjności przyrodniczej w migracjach seniorów (na przykładzie województwa ślaskiego) [in:] „Stare i nowe” problemy badawcze w geografii społeczno-ekonomicznej Zeszyt 5, PTG Oddział Katowicki, red. S. Sitek, Sosnowiec, 2014

[13] Pytel S. Atrakcyjność turystyczna miejsc migracji seniorów z województwa ślaskiego; Uniwersytet Szczeciński, Zeszyty Naukowe Nr 805, Ekonomiczne Problemy Turystyki nr1, Szczecin, 2014

[14] Ravenstein, E. G. The laws of migration. Journal of the statistical society of London, 48(2), pp. $167-235,1885$

[15] Ravenstein, E. G. The laws of migration. Journal of the royal statistical society, 52(2), pp. 241-305, 1889

[16] Runge J. Ludność, [in:] Studium wiedzy o regionie ślaskim, red. A. Szajnowska-Wysocka, Prace Naukowe UŚ, Katowice, nr 1755, pp. 15-49. 1999

[17] Sitek S., \& Runge J., \& Kłosowski F., \& Runge A., \& Petryszyn J., \& Pytel S., \& Spórna T, \& Kurpanik M., \& Zuzańska-Żyśko E. Społeczno-gospodarcze i przestrzenne kierunki zmian regionalnego oraz lokalnych rynków pracy województwa ślaskiego - Prace Wydziału Nauk o Ziemi Uniwersytetu Śląskiego, Sosnowiec, 2013

[18] Sojka E. Migracje ludności i rozwój demograficzny Śląska w okresie transformacji. Prace Naukowe/Akademia Ekonomiczna w Katowicach, 2007

[19] Szajnowska-Wysocka A., Aspekty $i$ walory metodologiczne zjawiska migracji, [w:] D. Szymańska (red.), Procesy i formy ruchliwości przestrzennej ludności w okresie przemian ustrojowych, praca zbiorowa, Uniwersytet Mikołaja Kopernika, Toruń, pp. 27-36, 2000a

[20] Szajnowska-Wysocka A. Methodological Aspects and Values of Migration Phenomenon, [w:] Processes and Forms of the Spatial Mobility of Population in the Period of Political System Transformation, Polish Population Revue, 17, Polish Demographic Society, Central Statistical Office, Warsaw, p. 35-44, 2000b

[21] Wpływ mobilności zawodowej i migracji na rynek pracy miast i regionów, (red.), Krzysztofik R., Urząd Miejski w Dąbrowie Górniczej, Dąbrowa Górnicza, pp. 108., 2011

[22] Zuzańska-Żyśko E. Procesy metropolizacji. Teoria i praktyka, PWN, Warszawa, pp. 432. 2016

[23] Zuzańska-Żyśko E., Pytel S., Koman W., Suburbanization in Postindustrial Area. Case Study of The Silesia Metropolitan Region [w:] Efe R., Cürebal I., Lévai L. (red.), GeoMed 2016. 4th International Geography Symposium. Book of Proceedings, Kemer, Antalya (Turkey), pp. 835849,2016 